\title{
Suicides and Epidemiological Parametrs of Tuberculosis in Russia
}

\author{
Yury E. Razvodovsky \\ Grodno State Medical University, Grodno, Belarus
}

\begin{abstract}
Tuberculosis and suicide are related to medical and social problems, and these epidemiological parameters are often considered as the indicators of psychosocial distress. There are theoretical assumptions and empirical evidence which suggest the positive association between suicide and mortality from tuberculosis at individual and population levels. The aim of this study was an attempt to identify the aggregate level relationship between the epidemiological parameters of tuberculosis and the suicide rates in Russia. Tuberculosis incidence / mortality and suicide rates were analyzed from 1980 to 2015 using time series analysis to evaluate the relationship between time series. The results of the analysis indicate the presence of a statistically significant association between tuberculosis mortality and suicide rates at lag zero ( $r=0.6$; SE $=0.17)$. The relationship between the incidence of tuberculosis and suicide rates was also positive, but less evident ( $r=$ 0.4; SE=0.17). The results of this study suggest a positive aggregate-level relationship between tuberculosis mortality and suicide rates. These findings indirectly support the hypothesis that tuberculosis mortality can be considered as an indicator of psychosocial distress.
\end{abstract}

Key words: tuberculosis incidence, mortality, suicide, trends, Russia, 1980-2015

Copyright (C) 2018 KBCSM, Zagreb

e-mail: alcoholism.kbcsm@gmail.com •www.http://apr.kbcsm.hr

\section{Introduction}

Until recently, Russia was among the countries with the highest mortality rate from tuberculosis and suicide $[5,20,13]$. Tuberculosis was one of the so-called social diseases; therefore the epidemiological parameters of tuberculosis are often used as an indicator of social well-being in the country [19]. One study showed that unemployment, low in-

Correspondence to: Yury E. Razvodovsky

Grodno State Medical University, 80 Gorky Street, Grodno 230009, Belarus

tel.: + 37501527018 84, fax: +375 01524353 41,

e-mail: razvodovsky@tut.by

yury_razvodovsky@mail.ru comes, poor living conditions and unbalanced diet are risk factors for tuberculosis death in the Urals, which is one of the most unfavorable regions of Russia [12]. In the Kaluga region, the risk of morbidity and mortality of the population from tuberculosis increases with a decrease in the able-bodied part of the population, an outflow of investments from the region, deterioration in living conditions, and a decrease in the level of employment of the population [7].

At first glance, the existence of a link between suicide and tuberculosis mortality seems doubtful since suicidal behavior is a 
psychosocial phenomenon, while tuberculosis is an infectious disease. However, there are at least several possible aspects of such link at the individual level. First, there are arguments in favor of the psychosomatic nature of tuberculosis [2]. Here, the common etiological factor of suicidal behavior and tuberculosis can be psychosocial distress accompanied by a decrease in the immunity, in general, the body's resistance, which increases the risk of tuberculosis [2]. Besides, an important aspect of existence of relationship between the suicidal behavior and tuberculosis is a suicidal behavior of patients with tuberculosis. One of the most common mental disorders in patients with tuberculosis is depression, which increases the risk of suicide [9]. The literature also reports of an increase in the risk of suicidal behavior against the background of antituberculosis drugs [8].

In general, the mortality rate of tuberculosis patients from external causes: injuries, alcohol poisoning, murders and suicides, is 4 times higher than in the common population [11]. A number of previous studies have attempted to identify the relationship between suicide and tuberculosis mortality at the population level. In one of them, it was shown that between 1990 and 1995, in 15 countries of Eastern Europe, the suicide rate was positively correlated with the death rate from tuberculosis ( $\mathrm{r}=0.58, \mathrm{P}<0.05)$, while in 17 of Western Europe countries there is no such a correlation [6]. At the same time, the level of both types of mortality was significantly higher in the countries of Eastern Europe. On the basis of these data, a hypothesis was proposed, according to which the level of mortality from tuberculosis, along with the level of suicide can be an indicator of the socio-economic crisis.
A later study showed a close relationship between the trends in suicide rates and mortality from tuberculosis in the late $1980 \mathrm{~s}$ and early $1990 \mathrm{~s}$ in Belarus, which confirms the important role of the psychosocial distress caused by the socioeconomic crisis in the etiology of suicide and death from tuberculosis $[15,16]$. It was also suggested that the level of suicide is a more sensitive indicator of the psychosocial distress than the death rate from tuberculosis due to the latency of tuberculosis [22].

The aim of this study was an attempt to identify the relationship between the epidemiological parameters of tuberculosis and the suicide rates at the population level in Russia. For this purpose, a comparative analysis of trends in suicide and tuberculosis incidence/ mortality rates in Russia was conducted.

\section{Subjects and Methods}

Data. The data on suicides and deaths from tuberculosis, as well as the incidence (morbidity) of tuberculosis for the period from 1980 to 2015 (according to Rosstat) were used in the study. The death rate from tuberculosis is one of the most informative and reliable indicators since it is least susceptible to distortions and reflects the epidemic situation with a higher extent of reliability [3].

Statistical Analysis. To examine the relationship between the variables throughout the studied period a time series analysis was performed using the statistical package "Statistica 10. StatSoft."

Bivariate correlations between the raw data from two time series can often be spurious due to common sources in the trends and due to autocorrelation [1]. One way to reduce the risk of obtaining a spurious relationship between two variables that have common 
trends is to remove these trends by means of a 'differentiation' procedure. The next stage involves investigating the cross-correlation function between two "whitened" series.

\section{Results}

The suicide rate declined significantly between 1984 and 1986, increased sharply between 1991 and 1994, again declined from 1994 to 1998, and then increased again between 1998 and 2001, after which it began to decline (Figure 1). The death rate from tuberculosis declined significantly between 1984 and 1986, then increased dramatically between 1991 and 1996, declined between 1996 and 1998, markedly increased during the period from 1998 to 2005, and then began to decline. The dynamics of the incidence of tuberculosis has demonstrated a slightly different pattern. This parameter in- creased sharply in the period from 1990 to 2004, after which it began to decline.

Visual analysis of graphical data (Figure 1) indicates that the time series under study are not stationary, since they have a pronounced trend. The attempt to remove the trend by the least squares method did not allow us to bring the time series to a stationary view. Therefore, the next step was to remove the nonstationary component by the differentiation method. After removing the deterministic component, the relationship between the time series was evaluated. Cross-correlation analysis of the converted time series showed that there was a statistically significant correlation between the dynamics of the suicide rate and mortality from tuberculosis at lag zero stock $(r=0.6, S E=0.17)$. The relationship between the incidence of tuberculosis and suicide rates was also positive, but less pronounced $(r=0.4 ; \mathrm{SE}=0.17)$.

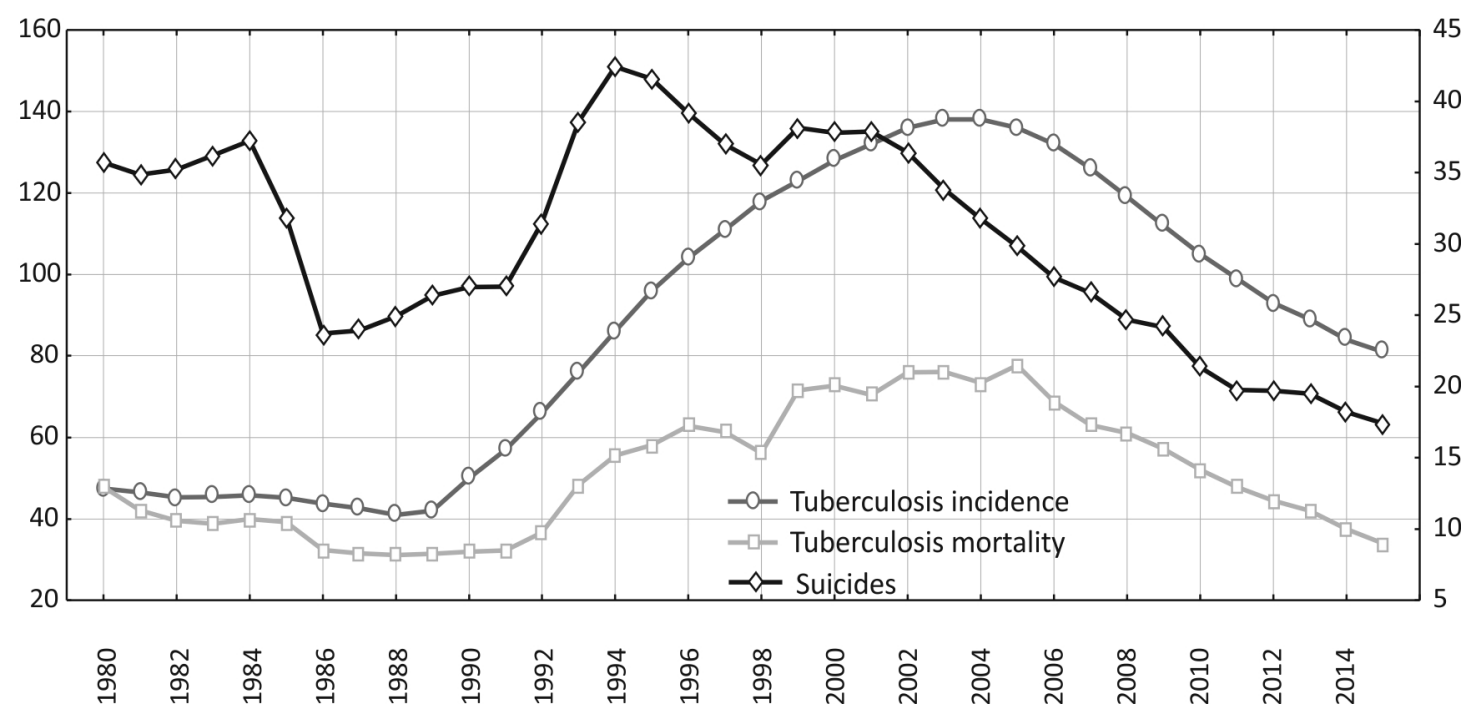

Figure 1. Trends in the suicide rate (right scale), tuberculosis incidence rate (left scale) and tuberculosis mortality rate (right scale) in Russia between 1980 and 2015. 


\section{Discussion}

According to the results of present analysis, there was a positive and statistically significant link between suicide and tuberculosis incidence/mortality trends in Russia between 1980 and 2015. The scale of this link was somewhat less obvious for the incidence of tuberculosis. These results replicate previous findings that suggest a close link between suicides and tuberculosis mortality at the aggregate level [6] and indirectly support the hypothesis that the death rate from tuberculosis is an indicator of psychosocial distress.

It is obvious that the psychosocial distress caused by the socio-economic crisis and the sharp decline in the standard of living of the population was an important determinant of growing suicide and tuberculosis mortality rates in the early 1990s. This is especially true for men, as they are more susceptible to the negative impact of socio-economic upheavals [4]. Given this fact, it can be assumed that the psychosocial distress associated with the 1998 banking crisis caused another spike in mortality from suicide and tuberculosis in subsequent years.

Some, in contrast to the previous events, were the lack of suicide and death rates from tuberculosis in response to the 2008 economic crisis. Apparently, this crisis, unlike the previous ones, did not produce such a significant negative impact on the standard of living of the population. The presumptive reasons for the reduction of tuberculosis mortality in the coming years are: stabilization of the social and economic situation and improvement of the living standards of the population, improvement of health financing, and improvement of the quality of tuberculosis treatment among the population [21].
Since the phenomena we are studying are relatively independent of each other, we are talking about coinciding trends, formed under the influence of some general unaccounted factors. One of these potential factors is alcohol. The specific weight of the alcohol factor in the structure of suicides in Russia varies from 45 to $59 \%$ according to various estimates [18]. With regard to the contribution of alcohol to the death rate from tuberculosis in a recent study using Russian data the alcohol attributable fraction in the structure of this type of mortality was estimated at $35.4 \%$ for men and $32.0 \%$ for women [9]. The influence of the alcohol factor on suicide rates and mortality from tuberculosis was clearly manifested during the period of 1985-1988 anti-alcohol campaign of, which is the most famous experiment in the field of alcohol policy [14]. A sharp decrease in the availability of alcohol during this period was accompanied by a significant reduction in the level of suicide, as well as mortality from tuberculosis.

It should also be noted that the deterioration in the quality of the data of the postSoviet period was a limitation of this study. A number of researchers indicate that because of the social significance of certain types of mortality from external causes, including suicide, certain manipulations with mortality statistics take place [4]. The problem of data quality is also related to epidemiological parameters of tuberculosis [9]. The reliability of data on mortality from tuberculosis depends on the quality of diagnosis of the causes of death of tuberculosis patients from tuberculosis and concomitant diseases. Some researchers note that when filling out medical death certificates, many mistakes are committed which distort the official statistics [10]. The quality of tuberculosis care to the 
population has a significant impact on the mortality rate from tuberculosis. Such factors as: inadequate financing of antituberculosis measures, reduction in the control surveys among population, reduction of the vertical management of the TB service and its isolation from the general treatment network, were one of the reasons for the dramatically increase in the tuberculosis death rate in the first half of the 1990s [20].

In conclusion, the results of this study suggest a positive aggregate-level association

\section{References}

1. Kandryichyin SV. Istoricheskie i sotsiokulturnyie aspektyi epidemiologii tuberkuleza. Pskovskiy regionologicheskiy zhurnal. 2017;1:46-58.

2. Shilova MV. Vzglyad na epidemicheskuyu situatsiyu s tuberkulezom v Rossiyskoy Federatsii (v sovremennyih sotsialno-ekonomicheskih usloviyah). Rossiyskiy elektronnyiy zhurnal luchevoy diagnostiki. 2014;4:34-42.

3. Razvodovsky YE. Suicide and fatal alcohol poisoning in Russia, 1956-2005. Drugs: Education, Prevention and Policy. 2009;16:127-39.

4. Razvodovsky YE. Alcohol consumption and suicide rates in Russia. Suicidol Online. 2011;2:67-74.

5. Shilova MV. Smertnost naseleniya i bolnyih tuberkulezom ot tuberkuleza i drugih prichin i faktoryi, okazyivayuschie vliyanie na ee uroven. Infektsionnyie bolezni. Spetsvyipusk. 2015;1:32-7.

6. Podgaeva VA, Golubev DN, Chernyaev IA, Shulev PL. Vliyanie sotsialno-ekonomicheskih faktorov na smertnost naseleniya tuberkulezom na Urale. Sibirskiy meditsinskiy zhurnal. 2011;26:151-8.

7. Lapshina IS, Myakisheva TV. Vyiyavlenie vliyaniya sotsialno-ekonomicheskih faktorov na uroven zabolevaemosti, rasprostranennosti i smertnosti between mortality from tuberculosis and suicide mortality. These findings indirectly support the hypothesis that mortality from tuberculosis can be considered as an indicator of psychosocial distress.

\section{Acknowledgments}

None

\section{Conflict of interest}

None to declare naseleniya ot tuberkuleza v Kaluzhskoy oblasti. Meditsinskiy vestnik Yuga Rossii. 2016;1:56-8.

8. Broytigam V, Kristman P, Rad M. Psihosomaticheskaya meditsina. Moskva: GEOTAR Meditsina. 1999; 373.

9. Nechaeva OB, Shestakov MG, Skachkova EI, Fursenko SN. Sotsialno-ekonomicheskie aspektyi tuberkuleza. Problemyi upravleniya zdravoohraneniem. 2010;6:16-22.

10. Mathew TA, Ovsyanikova TN, Shin SS, Gelmanova I, Balbuena DA, Atwood S, et al. Causes of death during tuberculosis treatment in Tomsk Oblast, Russia. Int J Tuberc Lung Dis. 2006;10:857-63.

11. Peltzer K \& Louw J. Prevalence of suicidal behavior \& associated factors among tuberculosis patients in public primary care in South Africa. Indian J Med Res. 2013;138:194-200.

12. Kondrichin S \& Lester D. Tuberculosis and suicide. Psychol Rep. 2001;89:326.

13. Razvodovsky YE. Prodazha alkogolya i smertnost ot tuberkuleza legkih. populyatsionnyiy uroven svyazi. Problemyi tuberkuleza i bolezney legkih. 2004;9:53-5.

14. Razvodovsky YE. Smertnost ot tuberkuleza i suitsidyi v Belarusi v period s 1970 po 2005 
gg. Problemyi tuberkuleza i bolezney legkih. 2007;7:23-5.

15. Vega P, Sweetland A, Acha J, Castillo H, Guerra $\mathrm{D}$, Smith Fawzi MC, et al. Psychiatric issues in the management of patients with multidrug-resistant tuberculosis. Int J Tuberc Lung Dis. 2004;8:749_ 59.

16. Filippova TP, Vasileva LS, Kochkin AV, Savvateeva VG, Shemetov AV \& Rusak DM. Sovremennyie tendentsii epidemiologicheskoy situatsii po tuberkulozu v Rossii. Sibirskiy meditsinskiy zhurnal. 2009; 90: 13-6.

17. Box GEP, Jenkins GM. Time Series Analysis: forecasting and control. London: Holden-Day Inc.;1976.

18. Gavrilova NS, Semyonova VG, Dubrovina E, Evdokushkina GN, Ivanova AE, Gavrilov LA. Rus- sian Mortality Crisis and the Quality of Vital Statistic. Popul Res Policy Rev. 2008;27: 551-74.

19. Streltsov VV, Zolotova NV, Baranova GV, Ahtyamova AA. Psihologicheskaya reabilitatsiya bolnyih tuberkulezom legkih na razlichnyih etapah terapii. Konsultativnaya psihologiya i psihoterapiya. 2015;2:57-77.

20. Razvodovsky YE. The effects of alcohol on suicide rate in Russia. J Socialomics. 2014;3:1-6.

21. Razvodovsky YE. Fraction of Tuberculosis Mortality Attributable to Alcohol in Russia. J Alcohol Drug Depend. 2015;3:1-4.

22. Nechaeva OB, Skachkova EI, Kucheryavaya DA. Monitoring tuberkuleza v Rossiyskoy Federatsii. Tuberkulez i bolezni legkih. 2013;12:40-9.

\section{Samoubojstva i epidemiološki parametri tuberkuloze u Rusiji}

Sažetak - Tuberkuloza i samoubojstvo su povezani s medicinskim i socijalnim problemima, i epidemiološki parametri se često smatraju indikatorima psihosocijalne neprilike. Postoje teoretske pretpostavke i empirijski dokazi koji navode pozitivne asocijacije između samoubojstva i smrtnosti od tuberkuloze na individualnoj razini i na razini stanovništva. Cilj ove studije je bio pokušaj identifikacije odnosa agregatne razine između epidemioloških parametara tuberkuloze i stope samoubojstava u Rusiji. Učestalost tuberkuloze/smrtnost i stope samoubojstva su se analizirale od 1980. do 2015. koristeći analizu vremenske serije kako bi se procijenila veza između vremenskih serija. Rezultati analiza ukazuju na prisutnost statistički značajnih asocijacija između smrtnosti od tuberkuloze i stope samoubojstava na lag zero ( $r=0,6 ; S E=0,17)$. Povezanost između učestalosti tuberkuloze i stope samoubojstva su također bile pozitivne, ali manje očigledne ( $r=0,4 ; S E=0,17)$. Rezultat ove studije navodi pozitivan odnos agregatne razine između smrtnosti od tuberkuloze i stope samoubojstava. Ovi zaključci indirektno podržavaju hipotezu da se smrtnost od tuberkuloze može smatrati indikatorom psihosocijalne neprilike.

Ključne riječi: učestalost tuberkuloze, smrtnost, samoubojstvo, trend/kretanje, Rusija, 1980.-2015. 